\title{
トランス酸に関する最近の話題 一国際的な動向と国内の現状について—
}

\author{
永田 純一
}

（独立行政法人国立健康・栄養研究所 食品保健機能プログラム食品分析プロジェクトリーダー）

\section{Current topic on trans fatty acids \\ - International trend on trans fatty acids and current situation in Japan-}

\author{
Junichi Nagata \\ Food Function and Labeling Program, Incorporated Administrative Agency, National Institute of Health and \\ Nutrition, 1-23-1 Toyama Shinjuku-ku Tokyo, 162-8636, Japan
}

テ162-8636 東京都新宿区戸山 1-23-1

\begin{abstract}
Trans fatty acids (TFA) are positional isomers of cis fatty acids. TFA are mainly produced by partial hydrogenation of unsaturated fatty acids and widely found in a variety of foods, including margarines, shortening and frying oil. A small amount of TFA is also found in ruminant fats and milk. The amount of TFA intake in Western Europe and North America probably ranges from 5 to $15 \mathrm{~g} /$ day. Epidemiological studies have shown that the excessive consumption of TFA raises LDL-cholesterol and lowers HDL-cholesterol in humans. Therefore, high intakes of TFA are thought to be a risk factor of coronary heart disease. On the basis of the scientific evidence, the U.S. FDA required labeling of the TFA content in conventional food and dietary supplement on January 1, 2006. TFA intake in Japan is estimated to be approximately 0.7 to $1.3 \mathrm{~g} /$ day, the amount is markedly lower than that in western countries. Although the low TFA intake in Japan is not thought to be an important issue at present, we should pay attention to an excessive intake of TFA in the future.
\end{abstract}

\section{はじめに}

近年，欧米に拈いてトランス型脂肪酸（以下トランス 酸）過㮃摄取と心疾患のリスク因子である血中脂質濃度 （特に LDL-および HDL-コレステロール濃度）の関連 性が多くの疫学研究によって明らかにされ，食品中トラ ンス酸量の表示義務化や摂取量勧告などの対応が行われ ている。これまで心疾患の罹患率が高い国では, 油脂の 摂取量や摂取される油脂の質を中心に心疾患予防や心疾 患リスク因子の改善に対する取り組みが行われてきたが， トランス酸も心疾患リスク因子として認識され始めた。 海外での動向を反映して日本国内でもトランス酸に対す る関心が高まっている。

今回，心疾患のリスク因子との関連性が指摘されてい るトランス酸 (水素添加による加工油脂に含まれるもの) について，トランス酸の概要（トランス酸とはどんな脂 肪酸なのか，トランス酸を含む食品など）や心疾患との
関連性，欧米諸国のトランス酸摂取状況や対策，また日 本国内でのトランス酸摂取状況などについて最近の話題 を紹介する。

\section{脂肪酸の構造とトランス酸}

脂肪酸は, 飽和脂肪酸々不飽和脂肪酸に分類される。 不飽和脂肪酸の炭素間結合様式にはシス型とトランス型 がある。これらの炭素にはそれぞれ水素原子が結合して いるが，水素の結合方向が同じ向きのものをシス型，互 い違いになっているものをトランス型という（図 1)。 トランス酸は, 不飽和脂肪酸のうち二重結合の立体配位 がトランス型になっているものの総称である。オレイン 酸（9c-18:1）の異性体であるエライジン酸（ 9 t-18: 1）は代表的なトランス酸として知られている（図 2$) 。$ 加工油脂中のトランス酸は, シス型脂肪酸が高温処理 されることで生じる場合や水素添加による製造工程で生 じる。この際に二重結合の転移も起こる。これらのトラ 


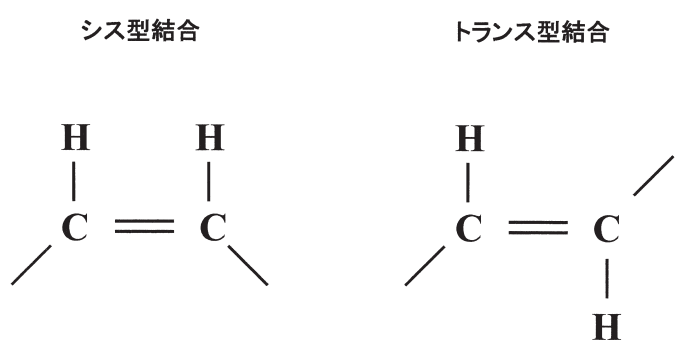

図 1 シス型およびトランス型結合様式

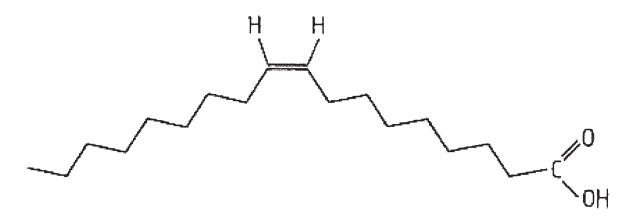

シス型脂肪酸:オレイン酸 $(c 9-18: 1)$

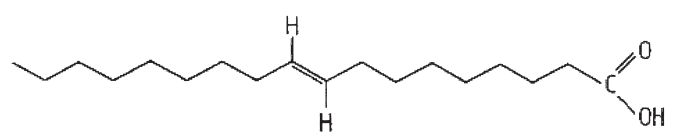

トランス型脂肪酸: エライジン酸 ( $\mathrm{t} 9-18: 1)$

図 2 シス型およびトランス型脂肪酸

ンス酸はマーガリンやショートニングなどの加工油脂中 やこれらを用いて製造される食品中に含まれる。この他 に反岛動物の肉や乳あるいは脂肪中にも5\%前後のトラ ンス酸が含まれる。反芻動物由来のトランス酸は，第一 胃内に存在するバクテリアによりシス型脂肪酸から生成 される。代表的なトランス酸はバクセン酸（11t-18:1） であるが，近年，反虫動物の肉や乳脂肪中にわずかに含 まれる共役リノール酸（CLA）の機能性が注目を集め ているが1)，コーデックス委員会（The Codex Alimentarius Commission : Codex）では共役結合を有する脂肪 酸はトランス酸に含まないと定義している。図 3 に示す ように C18：1のトランス酸も反忽動物に含まれるもの と水素添加してできるものとではトランス型結合位置が 異なり，工業的に生成したトランス酸と自然界のトラン

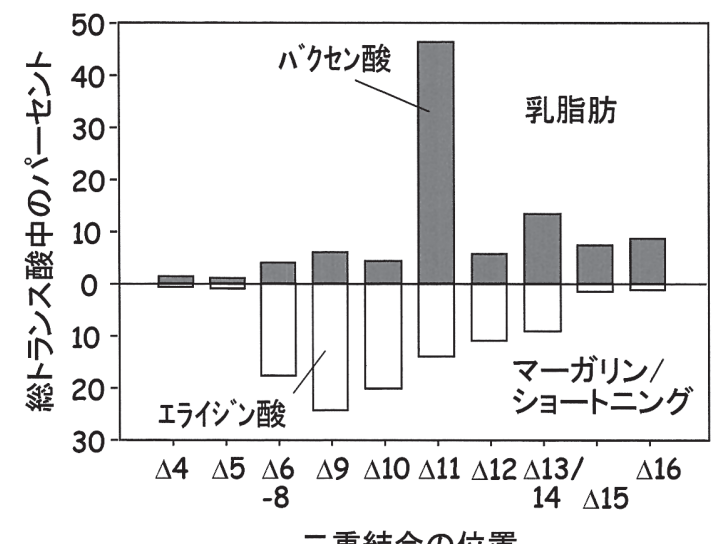

\section{二重結合の位置}

図 3 トランス18：1酸の位置異性体の分布 (Molkentin J and Precht D. E. Ernahrungswiss.1995)
ス酸ではトランス酸の位置が異なることが明らかになっ ている2)。水添油脂と反忽動物由来卜ランス酸の生理活 性は同じなのか？ また，代謝の相違はないのか？こ れらに関する十分な知見は得られていない。

ちなみに水素を添加して作られる代表的な加工油脂で あるマーガリンとショートニングは以下のように区別さ れる。

マーガリン類 : 基本的に食用油脂に水等を加え乳化し た後，急冷練り合わせをたは急冷練り合わせを行わない で作られた可塑性のもの又は流動状のものと定義され， 油脂含有率（製品に占める食用油脂の重量割合）が $80 \%$ 以上のマーガリンと $80 \%$ 未満のファットスプレッドから なる。

ショートニング : 植物, 動物油脂を原料とした練り込 久専用の固形油脂。水分や乳成分を含まず（品質規格で 水分は $0.5 \%$ 以下), ほぼ $100 \%$ が油脂成分からなり, 白 色無味無臭である。

今日欧米諸国に㧧いて心疾患との関連性が注目されて いるトランス酸は, 加工油脂に含まれるトランス酸と考 えられている。水素添加された油脂は, 不飽和脂肪酸と 比較して融点が上昇し酸化安定性などの物理化学的特性 が向上するため老化しにくい油脂となる3)。加工油脂は， マーガリンだけでなくパン，ケーキ，菓子製造用あるい は調理用フライ油として様々な食品（ポテトチップス, フライドポテト，フライドチキン）に利用されており， 日常生活で摂取する機会が多い。トランス酸拱取量が多 い欧米諸国では, 加工油脂技術の進歩と共に加工油脂中 のトランス酸含量を減らす工夫も行われている。現在行 われている主な方法を表 1 に挙げた。この中でも飽和脂 肪酸を含む油脂をトランス酸の代わりに添加した油脂が 利用されているが，飽和脂肪酸との置き換えによる飽和 脂肪酸摂取量の増加は必ずしも望ましい方法とは言えな い。特に, 植物油由来の飽和脂肪酸を含むパーム油を代 替として用いる場合があるが，パーム油はパルミチン酸 を約 $40 \%$ 程度含んでおり, Pedersen JI らが示した血清 コレステロール濃度に及ぼす食事脂肪酸の影響予測式 $(\Delta$ Total cholesterol $(\mathrm{mmol} / \mathrm{L})=0.01 \Delta \mathrm{C} 12: 0+0.12$ $\Delta \mathrm{C} 14: 0+0.057 \Delta \mathrm{C} 16: 0+0.039 \Delta$ trans $\mathrm{F}+0.031 \Delta$ trans $\mathrm{V}-0.0044 \Delta \mathrm{C} 18: 1-0.017 \Delta(\mathrm{C} 18: 2, \mathrm{C} 18: 3)$; trans F は硬化魚油, trans V は部分水素添加大豆油 $)^{4)}$ から考えるとパルミチン酸摂取の増加は, トランス酸摂

表 1 トランス酸の低減あるいは除去の取り組み
1. 水素添加法の改良
2. 分別
3. エステル交換
4.ブレンディング
5 . 遺伝子組み換え操作
6. エマルション法
7. $1 \sim 6$ の組久合わせ 
取と同等以上のコレステロール濃度の上昇に寄与 することが分かる。また WHO も心疾患との関連 から飽和脂肪酸摂取量の増加に注意を促している ことから必ずしも適切な代替法とは言えない。

\section{トランス酸の生理学的影響}

トランス酸は飽和脂肪酸と類似の生理効果を示 すと考えられている。トランス酸の過剩摂取は, 血清 LDL コレステロール濃度上昇や HDL コレス テロール濃度の低下, Lp（a）の増加5)，トリグリ セリド (中性脂肪 $)^{6)}$ や血管内皮への影響7)など様々 な心疾患のリスク因子に影響することが疫学研究 によって報告され，これらはトランス酸摂取量に 依存的であることが示されているが，トランス酸 によるコレステロール代謝メカニズムの解明には至 っていない。

Zockらは，ヒトに打けるトランス酸摂取量とリ ポタンパク質コレステロール濃度との相関性を調ベ, トランス酸摂取量の増加に伴い, LDL コレステロー ル濃度は正の相関を示し，HDL コレステロール濃 度は負の相関を示すことを明らかにしている8（図 4 )。また，トランス酸の過剰摂取は，動脈硬化症 のリスク指標である LDL/HDL 比にも影響を及ぼ す。Ascherioらは同じカロリーの飽和脂肪酸ある いはトランス酸を摂取した場合，トランス酸の $\mathrm{LDL} / \mathrm{HDL}$ 比は，飽和脂肪酸の值より約 2.5 倍大き くなることを示した ${ }^{9)}$ このようにトランス酸を過 剰摂取した場合，同じカロリーの飽和脂肪酸よりも 心疾患のリスク因子に影響を及ぼすことが示唆され ている。

また欧米において総勢 145,000 人を対象に 6 ～14 年の追跡調查を実施した 4 つの大規模研究（Health Professionals' Follow-up Study, Alpha-Tocopherol, Beta-Carotene Cancer Prevention Study, Nurses' Health Study, Zutphen Elderly Study) からも，トランス酸摂 取と心疾患リスクとの相関性が示され，トランス酸摂取 量が $2 \%$ （エネルギー比）増加すると心疾患リスクが 1.25倍に増加するとしている。

しかし一方で，トランス酸による血漿コレステロール 濃度上昇作用は，総脂質摂取量を減らすよりもむしろ才 レイン酸やリノール酸に置き換える方が効果的に抑制さ れ，リノール酸拱取量が多いほどコレステロール濃度の 上昇は抑制されることが報告されており，トランス酸の 生理的効果は，同時に摂取される油脂の質や量によって 影響される可能性が高い。Hu FB らはトランス酸およ び多価不飽和脂肪酸の摂取量と心疾患リスクの関係を示 し, トランス酸の低い摂取量と多価不飽和脂肪酸摂取量 の増加が，心疾患のリスクを低く抑えることを示唆して いる10)（図 5 ）。彼らが示したそれぞれの摂取量は，卜 ランス酸が低いカテゴリーで1.3エネルギー\%，多価不

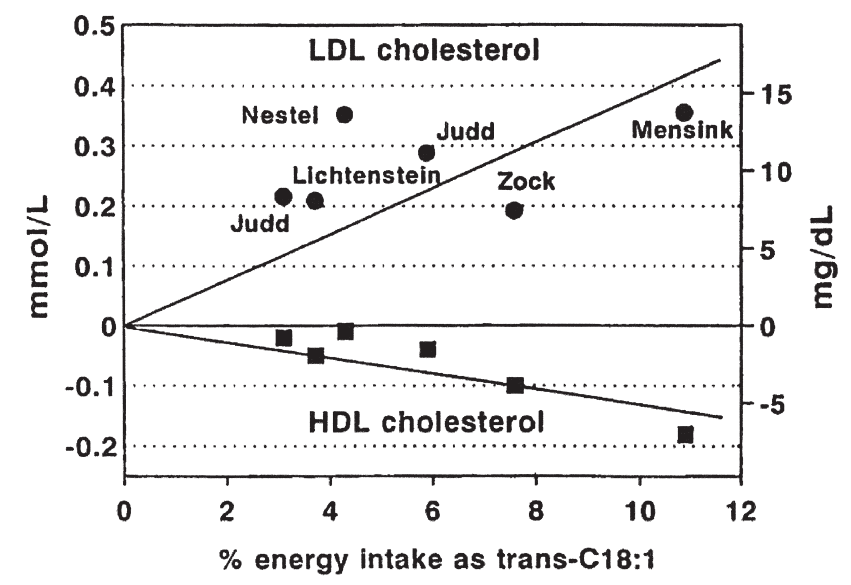

図 4 トランス酸摂取量とリポタンパク質コレステロール濃度の 相関性

(Zock PL. et al. N. Engl. J. Med. 1999)

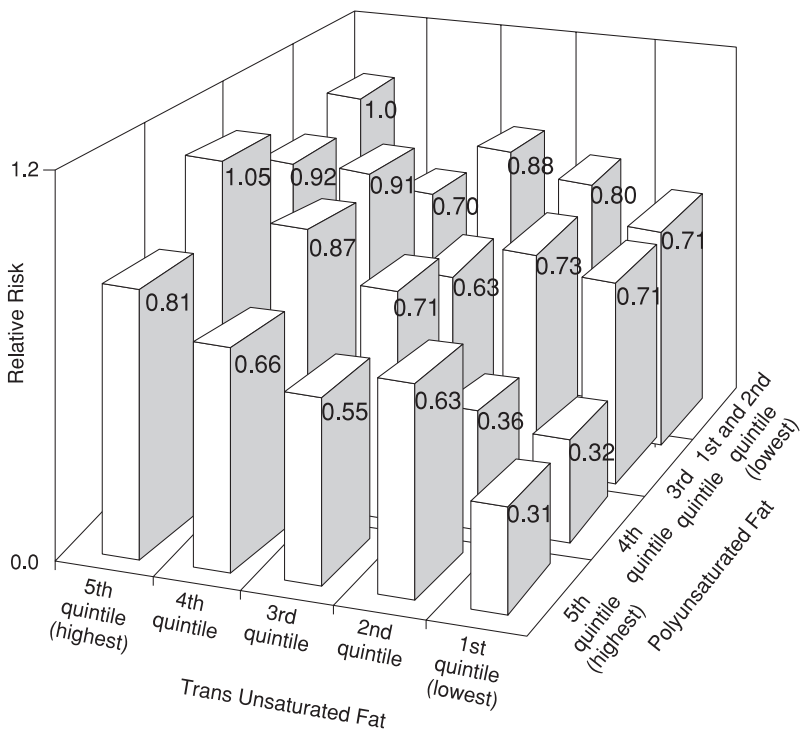

図 5 トランス酸および多価不飽和脂肪酸摂取と心疾患リスクの 相関性 (Hu FB. et al. N. Engl. J. Med. 1997)

飽和脂肪酸の最も高いカテゴリーで 6.4 エネルギー\%で あった。日本人のそれぞれの摂取量は，トランス酸が $0.3 \sim 0.6$ エネルギー\%, 多価不飽和脂肪酸がおよそ10\% といずれもさらに心疾患に及ぼす影響が低いカテゴリー に分類されると予測される。日本では欧米に比べ, リノー ル酸や魚油の摂取量が多い食事背景を考えれば，トラン ス酸の心疾患に及ぼすリスクはさらに軽減されると推定 される。

\section{トランス酸の摂取状況}

トランス酸の摂取状況は, 摂取する食事の聞き取り調 查による積み上げ方式によって算出されたり消費される 総脂質摂取量に占める割合から算出される。食品中のト ランス酸含量の幅は非常に大きいため, 拱取量のばらつ きも大きくなる。欧米諸国では1997年以前の10～15年間 におよぶ調査から，平均トランス酸摂取量はおよそ 5 $15 \mathrm{~g} /$ 日で総エネルギーの約 $2 \sim 5 \%$ と見積もられてい 


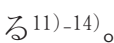

日本のトランス酸摂取状況は，これまで 1 日当たり平 均摂取量は $0.63 \mathrm{~g}$ であり, 摂取エネルギーの約 $0.3 \%$ か ら0.8\%の範囲に相当すると考えられていた ${ }^{15)}$ 。また 2007年 6 月に食品安全委員会から公表された日本人の卜 ランス酸摂取量もエネルギー比 $0.3 \sim 0.6 \%$ で，いずれも 日本人が摂取しているトランス酸量は欧米諸国の摂取量 （ $5 \sim 15 \mathrm{~g} /$ 日） と比較して少なく，WHO が推奨する摂 取目安量のエネルギー比 $1 \%$ 以下となる。日本人におけ るトランス酸摂取量から心疾患のリスクに及ぼす影響を 推定するのは難しいと思われる。

\section{トランス酸に対する諸国の対応}

アメリカ：1990年11月栄養表示基本法の成立を受け， 1993年よりコレステロール，飽和脂肪酸量が食品ラベル に表示されることが決なったが，この時点でトランス酸 は表示義務の対象項目から外れた。しかし，1980年代よ り行われてきた多くの疫学調査の結果から, アメリカ食 品医薬品安全局（FDA）は，トランス酸の過唾摂取が LDL コレステロール濃度の上昇と HDL コレステロー ル濃度の低下をもたらし，心筋梗塞をはじめとする心疾 患のリスク因子に関与する食事成分であると判断し， 2003年 7 月にトランス酸の表示を義務付ける規則が決定 され，2006年 1 月 1 日より加工食品のトランス酸含量の 表示義務化が施行された。この表示規則では，反芻動物 に含まれるトランス酸も含めた值がラベル表示される。 トランス酸過利摂取による心疾患のリスク因子への影響 を考慮し，トランス酸摂取量を総エネルギー摂取量の 1 $\%$ 以下（約 $2 \mathrm{~g}$ 以下）にするよう勧告も行われた。

アメリカでは行政のみでなく民間企業もトランス酸摂 取の低減に取り組んでいる。行政では，ニューヨーク市 が2008年 7 月より市内のレストランからトランス酸を含 むメニューを排除する方針を示し，他の都市も類似の方 針を示している。ただしニューヨーク市の場合，トラン ス酸量が 1 サービング当たり $0.5 \mathrm{~g}$ 以下のものはトラン ス酸フリーと見なされ販売することができる。一方民間 企業での取り組みとして，ケンタッキーフライドチキン では，フライドチキンを調理する油を水添硬化油からリ ノレン酸含量を低く抑えた遺伝子組久替え大豆油に置き 換えた。また，スターバックスコーヒーも大都市の店舗 を中心にマフィンやサンドウィッチなど全ての商品がト ランス酸を含まないものになり，2007年内に全店舗から トランス酸を追放する方針である。

カナダ : 原則として2005年12月より栄養成分の表示義 務化に括いて，トランス酸も表示対象としている。

$\mathbf{E U}: \mathrm{EU}$ ではアメリカと異なり, 食品に水素添加し てトランス酸を含む場合，含量ではなくトランス酸を含 むことを表記しなければならない。

デンマーク：2004年 1 月より国内で販売する加工食品 の油脂中トランス酸含有量を $2 \%$ (重量比) をでに制限
している（動物由来のトランス酸は除く）。従って，2 \%を超えるトランス酸を含む製品は販売できない。

オーストラリア・ニュージーランド：摂取量が総エネ ルギー比 $1 \%$ 弱と少なく, 現在のところ規制は予定され ていない。

韓国・台湾 : 現在は規制を行っていないが，韓国では 2007年12月にトランス酸, 台湾で2008年 1 月に飽和脂肪 酸とトランス酸の表示義務化を予定している。

またトランス酸に関する国際的な取り組みも Codex で行われているが，これまでのところトランス酸の定義 のみ示されているが，表示等に関しては各国の事情を子 まえた自主判断での対応を行うこととしている。

\section{トランス酸に対する日本の現状}

内閣府食品安全委員会は, 2004年に「日本では, 硬化 油, 乳, 乳製品, 肉, バター, 精製植物油の摂取量を考 慮して推計したトランス酸の摂取量は一日あたり平均 $1.56 \mathrm{~g}$ となって打り摂取エネルギーの $0.7 \%$ に相当する。 諸外国と比較して日本人のトランス酸摂取量が少ない食 生活からみて, トランス酸による健康への影響は小さい と考えられる。との見解を示した。2007年 6 月にも日 本人のトランス酸一日平均摂取量は摂取エネルギーの $0.3 \sim 0.6 \%$ であると発表を行い, 日本人は欧米と比較し てトランス酸摂取量が低い現状であることを示している。 これまでのところトランス酸に関する表示制度の確立や 摂取量勧告などは予定されていない。

\section{日本人における心疾患リスク因子への影響}

これまで示したように，日本人のトランス酸摂取量は 欧米諸国と比較して低い摂取量であることが明らかであ る。トランス酸摂取量の増加が心疾患リスク因子の増加 をもたらし罹患率および死亡率と高い相関を示す疫学調 査の結果は, トランス酸のエネルギー摂取量が約 $3 \%$ を 超えた摂取量の時である。それ以下の摂取量における心 疾患リスク因子への影響は明確に示されていない。食品 安全委員会から出された日本人の推定トランス酸摂取量 は打よそ0.3〜0.6エネルギー\%で，このように著しく低 い摂取量からトランス酸の心疾患へのリスクを予測する ことは非常に難しい。

日本人に対するトランス酸摂取の影響を考慮する際に 最も重要なことは, 日本人の食事（日本型食生活）が欧 米の食事（欧米型食生活）と脂質摂取量や摂取される脂 質の量および質の点で大きく異なるということである。 すなわち日本人は欧米人に比べ植物油からの n-6 系脂 肪酸や魚油からの $\mathrm{n}-3$ 系脂肪酸の摂取が多く, 欧米よ の脂質の摂取バランスに優れていると考えられる。植物 油や魚油をトランス酸と併用摂取した場合, トランス酸 の影響が軽減される可能性が大きいことを考慮すべきで はないだろうか。しかし，このような食事背景にあって も10代，20代におけるファーストフード嗜好性は憂慮す 
べきである。欧米スタイルの食事は, 総脂質摂取量の増 加とトランス酸摂取量の増加をもたらすため, ファース トフード嗜好の習慣化は心疾患のリスク因子に及ぼす影 響を大きくする。従ってトランス酸を含む食べ物を把握 し日常の食事バランスを考慮した食事が大事になる。

\section{まとめ}

アメリカFDAによるトランス酸の表示義務化が決定 されて以来，我が国のみならず国際的にトランス酸摂取 への関心が高まっている。我が国における脂質摂取状況 は，油脂の質や摂取量において欧米諸国と大きく異なる 背景があるが, 最近の食品安全委員会のファクトシート では「健康保護の観点から, 今後とも, 日本人（又は日 本での）の摂取量や各摂取レベルにおける健康への影響 等に関する国内外の新たな知見を蓄積して行くことが必 要」との見解を示している。

日本人の食を取り巻く環境や嗜好性が欧米化し，加工 油脂を用いて調理加工されたファーストフードやパン, スナック菓子などトランス酸を含む食品を摂取する機会 を多く，容易にトランス酸摂取量が増加する食環境でも ある。欧米のような過㮃摂取を行えば，疾病リスクの上 昇につながるため，日常の食生活におけるトランス酸の 過剰摂取には注意を払う必要がある。

\section{文献}

1) Nagao $K$, Yanagita T. Conjugated fatty acids in food and their health benefits. J.Biosci. Bioeng. 2005 ; 100 : 152-157.

2) Molkentin J, Precht D. Determination of trans-octadecenoic acids in German margarines, shortenings, cooking and dietary fats by AgTLC/GC. Z. Ernahrungswiss 1995 ; 34 : 314-317.

3）神村義則監修：〈新訂版〉食用油脂入門，日本食糧新聞社, 東京，135-149（2005）
4) Pedersen JI, Kirkhus B, Müller H. Serum cholesterol predictive equations in product development. Eur. J. Med. Res. $2003 ; 8: 325-331$.

5) Mensink RP, Katan MB. Effect of dietary trans fatty acids on high-density and low-density lipoprotein cholesterol levels in healthy subjects. N. Engl. J. Med. $1990 ; 323: 439-445$.

6) Ascherio A, Katan MB, Zock PL, et al. Trans fatty acids and coronary heart disease. N. Engl. J. Med. 1999 ; 340 : 1994-1998.

7) de Roos NM, Bots ML, Katan MB. Replacement of dietary saturated fatty acids by trans fatty acids lowers serum HDL cholesterol and impairs endothelial function in healthy men and women. Arterioscler Thromb. Vasc. Biol. 2001; 21: 1233-1237.

8) Zock PL, Mensink RP, Katan MB. Dietary trans fatty acids and lipoprotein cholesterol. Am. J. Clin. Nutr. 1995 ; 61, 617 (Letter).

9) Ascherio A, Katan MB, Zock PL, et al. Trans fatty acids and coronary heart disease. N. Engl. J. Med. 1999 ; 340 : 1994-1998.

10) Hu FB, Stampfer MJ, Manson JE, et al. Dietary fat intake and the risk of coronary heart disease in women. N. Engl. J. Med. 1997 ; 337 : 1491-1499.

11) Senti FR. Health aspects of dietary trans fatty acids. Federation of American Societies for experimental biology, Bethesda, 1-111 (1985).

12) British Nutrition Foundation's Task Force : Trans fatty acids. The British Nutrition Foundation, London, 5-7 (1987).

13) Enig $\mathrm{MG}$, Atal $\mathrm{S}$, Keeny $\mathrm{M}$, et al. Isomeric trans fatty acids in the U.S. diet. J. Am. Coll. Nutr. $1990 ; 9$ : 471-486.

14) Hunter JE, Applewhite TH. Reassessment of trans fatty acid availability in the U.S diet. Am. J. Clin. Nutr. 1991 ; $54: 363-369$.

15）岡本隆久, 松崎 寿, 丸山武紀他. 国産硬化油中のトラン 又酸とその摂取量. 日本油化学会誌，48：1411-1414（1999）

本稿は，第34回研究集会に打ける発題講演をまとめたものである。 